\title{
Curriculum response to the crisis
}

\author{
Patrick Charland $^{1}$ (D) Marion Deslandes Martineau ${ }^{1} \cdot$ Tegwen Gadais $^{1}$.

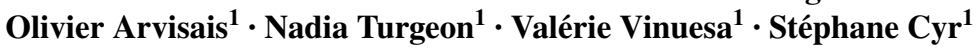

\begin{abstract}
Education is going through a period of crisis related to the SARS-CoV-2 pandemic that most probably will follow a continuum organized into distinct phases: emergency, recovery, reconstruction, development, and institutionalization. This article analyzes the response of curriculum to an unpredictable, chaotic, and recursive crisis situation. The article also highlights the role of important, but often forgotten, actors in a formal education system - parents - and examines the stresses the pandemic has placed on them. Finally, in the light of the continuum of the educational crisis and the impacts of Covid19 on certain curricular dimensions, the article concludes with reflections on the need to rethink curricula, even in education systems that considered themselves robust in their institutionalization.
\end{abstract}

Keywords Curriculum $\cdot$ Crisis $\cdot$ Continuum $\cdot$ Students $\cdot$ Parents

Patrick Charland and Marion Deslandes Martineau contributed equally to the article.

\section{Patrick Charland \\ Charland.patrick@uqam.ca}

$\triangle$ Marion Deslandes Martineau

Deslandes-martineau.marion@courrier.uqam.ca

Tegwen Gadais

Gadais.tegwen@uqam.ca

Olivier Arvisais

Arvisais.olivier@uqam.ca

Nadia Turgeon

Turgeon.nadia@courrier.uqam.ca

Valérie Vinuesa

Vinuesa.valerie@uqam.ca

Stéphane Cyr

Cyr.stephane@uqam.ca

1 Université du Québec à Montréal (UQAM), Montreal, QC H3C 3P8, Canada 
According to United Nations (UN) Secretary-General Antonio Guterres, the Covid-19 pandemic is the worst global crisis since the Second World War, partly because of the threat of the disease itself and partly due to its global economic impact (BBC News 2020). He states that "while the virus strikes indiscriminately, its effects are discriminatory, highlighting the gaping deficiencies in public services and the structural inequalities that impede access" (Guterres 2020). In addition to being a health and economic crisis, the pandemic is also an education crisis. Anderson et al. (2020, p. 931) note that although school closure is a widely implemented measure to slow the spread of viruses, there is no consensus on its effectiveness:

School closure, a major pillar of the response to pandemic influenza A, is unlikely to be effective given the apparent low rate of infection among children, although data are scarce. Avoiding large gatherings of people will reduce the number of superspreading events; however, if prolonged contact is required for transmission, this measure might only reduce a small proportion of transmissions. Therefore, broaderscale social distancing is likely to be needed, as was put in place in China.

With nearly 200 countries having imposed nationwide school closures, almost all students around the world, representing more than 1.5 billion young people, suffer the closures' prolonged effects (UNESCO 2020a). While policy makers have enacted plans to minimize the negative effects of school closures (UNESCO 2020b), its effects on curricula are certain to be major (Azzi-Huck and Tigran 2020), even more so for students from disadvantaged backgrounds (Berkman 2008). Significant consequences are to be expected-and are already being felt — at several levels (UNESCO 2020b), including student learning, development, and improvement; nutrition, for which many students are dependent on school services; the stress placed on parents, who find themselves in the role of educator without the necessary experience or resources; unequal access to learning technologies; family income, with parents playing the dual roles of worker and teacher; schools and child care facilities that remain open, where children who are deprived of school are massively redirected; and drop-out rate, which is likely to increase due to prolonged absence from school.

In this article, we ask how curricula can respond to fast-changing, unpredictable, and often disruptive events such as the Covid-19 outbreak. The methodological approach we chose to answer this question is a scoping review that provides insights from the international literature on crises, curricula, and the response of education systems to the pandemic. Scoping reviews are "a relatively new approach to evidence synthesis [and] provide an overview of the available research evidence without producing a summary answer to a discrete research question" (Sucharew and Macaluso 2019). They are useful when existing literature on a specific topic is emerging, sparse, diverse, and complex, as is the case for literature about the Covid-19 response and when seeking answers to broad questions such as ours (Peterson et al. 2017; Sucharew and Macaluso 2019).

\section{The continuum of the crisis}

We hypothesize that this crisis followed and will follow a continuum organized in distinct phases. This model has emerged from the work and research projects of the UNESCO Chair in Curriculum Development (UCCD 2020a), which has supported and analyzed education systems after crises, such as armed conflicts or coups d'état, in Africa, the Middle 


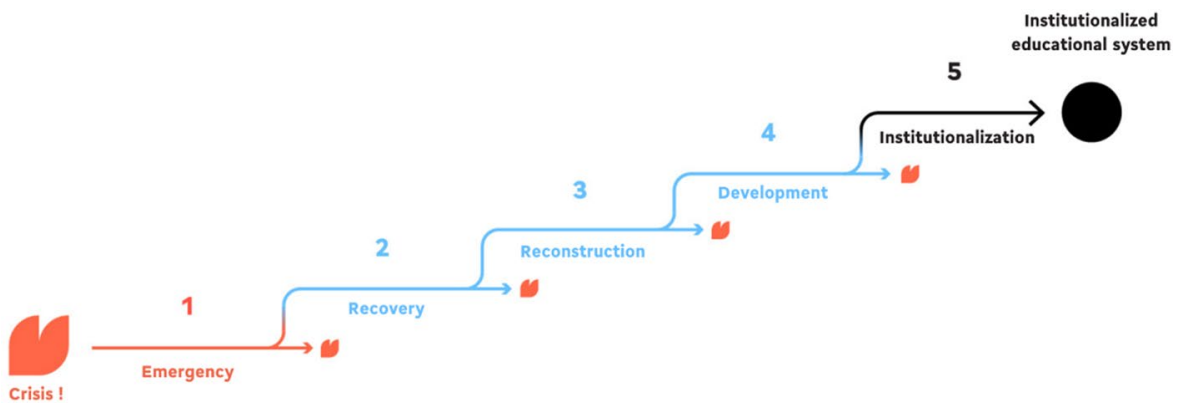

Figure 1 Continuum of the educational crisis. Source: Developed by the authors. Illustration by Audrey Wells and Marc Larivière

East, and South America. In light of the UCCD's work, it is likely that education systems in crisis will follow the phases illustrated in Figure 1.

First comes the crisis, the starting point of the continuum. We consider a crisis to be a sudden, unpredictable, and chaotic event that causes a rapid disruption in the functioning of a system or organization (Shaluf et al. 2003) and comprises a collective sense of uncertainty, threat, and urgency around a problem (Brinks and Ibert 2020). The nature of the crisis and its local and international importance will have various effects, but a crisis always involves the need for crucial decisions to be made in a short time (Darling 1994; Shaluf et al. 2003; Brinks and Ibert 2020). While the prevailing view is that a crisis is a negative situation, Shaluf et al. (2003) point out that "the notion of a positive outcome from a crisis situation is emerging from literature". Therefore, we consider a crisis to be an unstable situation from which can emerge either highly undesirable or highly desirable and positive outcomes, as illustrated by the Chinese symbol for crisis, weiji-a combination of the words "danger" and "opportunity" (Darling 1994). The panic, shock, danger, and chaos that crises provoke cause systems to move from one phase of the continuum to another, not linearly, but rather recursively (ALNAP 2010). As Brinks and Ibert (2020) mention, "Under such conditions, action does not take place within a given frame of meaning. Rather, in crisis, participants are forced to learn by interpreting the situation tentatively while acting on it".

The first phase of education systems in crisis is the emergency phase. This global state, which directly follows the crisis, requires immediate and graduated temporary measures, which are not necessarily part of a clear plan of action, aimed at minimizing the negative impacts of the crisis (EduScol 2015). These measures include meeting basic subsistence needs and saving lives (UNHCR 2006). In the case of the Covid-19 pandemic, rapid closure of schools and other physical containment and distancing measures are part of the emergency phase.

The second phase consists of restoring (the recovery phase) the capacity of governments and communities to recover-that is, to reorganize themselves to emerge from the crisis and avoid relapse: "Recovery helps people to get back on the path to development" (UNDP 2020). During this phase, temporary activities are put in place, often in haste, to get education actors back in action. Recovery activities can build on pre-crisis humanitarian actions to ensure that they are assets in the development phase. During the Covid-19 pandemic, for example, several education systems put in place temporary distance education measures, 
such as digital learning platforms, to ensure that students' learning achievements are maintained.

The third phase (the reconstruction phase) is defined in the Internationally Agreed Glossary of Basic Terms Related to Disaster Management (UN 1992) as "a full resumption of the predisaster state including all preventive measures". These activities, more institutionalized than those of the recovery phase, are implemented during and after the crisis and are aimed at addressing medium- and long-term issues affecting the components of the system. Activities implemented for the reconstruction of education systems worldwide during the current crisis include distance education (Burns 2020; UNESCO 2020a). Azzi-Huck and Tigran (2020) write:

Many countries have turned to distance learning as a means of mitigating for lost time in school (fully online in China, Italy, France, Germany, and Saudi Arabia; mobile phones or television in Vietnam, Mongolia). [...] Other countries send kids home with lessons as homework [all online] (Lebanon). In Bulgaria, more than 800,000 [online] accounts have been created for all teachers and parents, publishers have been mobilized to open the digital textbooks and learning materials for grades 1 to 10, and two national TV channels will broadcast educational TV.

The fourth phase is the process of overall development of a country or region's socioeconomic, intellectual, social, and cultural fabric. Development, therefore, aims at improving the education system: "Societies everywhere are undergoing deep transformation, and this calls for new forms of education to foster the competencies that societies and economies need, today and tomorrow" (UNESCO 2015, p. 3). Although it is primarily emerging countries that are developing their education systems, Covid-19 highlights the fragility of all systems and forces them to return to the development phase. Thus, the creativity and innovation that the crisis is accelerating can serve as levers for the development of greater systemic flexibility and resilience.

The fifth and final phase, that of institutionalization, concerns the establishment, formalization, sustainability, structuring, and social acceptance of systems within the state. Although every education system aims to reach this phase, Gérard (2001, p. 76) notes the following:

From one social group to another, from one social and economic context to another, educational practices and strategies have neither the same legitimacy nor the same rationality. And they all reflect a particular relationship, from individuals and groups, to the school situation, to the extent of the institutionalization of the school.

Therefore, institutionalization looks different depending on the political and social context. Given the scale of the pandemic and the resulting educational crisis—and taking into account the continuum of crises that education systems are likely to experience in recurrent phases-it is necessary to ask the following question: How can curricula respond to fastchanging, unpredictable, and often disruptive events, such as the Covid-19 outbreak?

\section{Curriculum response to the crisis}

Before we answer this question, we must adopt a definition of curriculum that will allow us to structure our discussion despite the conceptual diversity and lack of consensus on this matter (Breault and Marshall 2010; Schiro 2012). 
Jonnaert (2015) groups the definitions of curriculum into two contrasting perspectives. The Anglo-Saxon and North American vision of curriculum goes beyond that of an educational program. The curriculum, in this view, adopts a systemic perspective; it structures an education system through various action plans (administrative, pedagogical, evaluative, etc.) that are broad and inclusive, integrating a concern for the functionality of learning. The Franco-European curricular stream conceives the curriculum from a more programoriented perspective, oriented toward the very specific learning content of school subjects. For example, Reuter et al. (2007) see the curriculum as referring to the programming of teaching content, while Durand (1996, p. 107) writes: "A curriculum is a field of research and study which concerns the current and prospective situation of a school system in order to analyze the major trends and define the main lines of development".

To better analyze the impacts of Covid-19, we will use Connelly and Xu's conceptualization (2008) of the modern curriculum as having four dimensions (or commonplaces): teachers, students, subject matter, and milieu. This model derives from Schwab's framework of curriculum commonplaces (Schwab 1973; Joseph 2011), according to which the "teachers"" commonplace comprises not only teachers themselves but also their pedagogical views, flexibility, and personalities. The "students", of course, refers to the children and includes their abilities, aspirations, and qualities. "Subject matter" is the curriculum's disciplines of study, the materials they use, and its underlying system of thought. Finally, the "milieu" refers to the environment in which learning takes place (school, classroom), its social structure, and its influences. As Connelly and Xu (2008, p. 519) point out:

The curriculum, in this view, is a way to entwine the disparate and fragmented lines of inquiry that make up our modern educational world of scholarship. Curriculum is a way of integrating disparate lines of inquiry around the broad idea of experience in the relationships among teachers, students, subject matter, and milieu.

In using Connelly and $\mathrm{Xu}$ (2008) as our frame, we will also keep in mind the continuum of the crisis by highlighting recommendations raised in this reflection that are or should be part of the curricula response to the pandemic. Finally, we will call attention to the role of an important, but often forgotten, actor in a formal education system-the parent.

\section{Effects of the crisis on teachers}

Müller and Goldenberg (2020) point out that studies typically document the effects of crises on teachers much less than they do on students. The authors highlight two main potential effects on teachers.

First, the pandemic subjects teachers to the same challenges and tensions the general population faces, including dual professional and family responsibilities (Müller and Goldenberg 2020). Many teachers must maintain and create a daily routine and learning activities for their own children, as recommended by the World Health Organization (WHO 2020a), while doing so at a distance for their students (Lollia and Issaieva 2020). Like other parents, during the pandemic teachers with their own children have the added burden that "during times of stress and crisis, it is common for children to seek more attachment and be more demanding on parents" (WHO 2020a, p. 4). Pressures the teachers' experience in their professional role (Müller and Goldenberg 2020) compound this issue, especially during the emergency phase of the continuum, when a clear action plan may not exist and the many reversals in government instructions to teachers place them in a situation of constant uncertainty -including uncertainty with regard to their employment situation. 
Second, many teachers do not have adequate training and guidance to address students' socioemotional needs following a crisis (Müller and Goldenberg 2020). US studies of teachers in postcrisis situations have found they do not feel equipped to support students emotionally and that many feel overwhelmed by what is expected of them at school after a traumatic event (Pfefferbaum et al. 2004a, b). In working with traumatized students, teachers may experience secondary traumatic stress disorder (STSD), which occurs when a professional experiences the fear, pain, or suffering of the person they are caring for (Figley 1995). STSD can greatly affect the mental health of teachers, who may need professional and peer support to help them cope with these exceptional circumstances (Loescher 2020; UNICEF 2020). Müller and Goldenberg (2020, p. 29) argue that "ensuring that teachers are supported to manage stress and avoid exhaustion is imperative for both teacher and pupil wellbeing". We believe such support should be part of the activities put in place as soon as the reconstruction phase.

Moreover, as teachers are away from their workplaces and no longer see their students except virtually, the crisis has greatly altered teaching and planning practices. Distance education poses special challenges for the significant number of teachers who are uncomfortable with or lack training in the use of technology (Dede 2020; Lollia and Issaieva 2020). Attempting to provide quality distance education until the end of the school year while planning distance or hybrid teaching modalities for the fall represent a major source of anxiety for many teachers. In an educational crisis, what we take for granted no longer holds, and "educators find themselves both freed from what was but also in free fall into what is a new reality" (Loescher 2020).

Studies of education in emergencies (Burde et al. 2015) lead to the identification of three main issues during school closures related to the pandemic (Arvisais et al. 2020): access to education and technology, quality of education and support for parents, and student wellbeing. Those orientations and the actions they suggest should be part of the emergency or early reconstruction phase, as they aim to minimize the negative effects of the crisis.

Anderson et al. (2020) observe that in the United States roughly one-third of households with children ages 6-17 and an annual income below \$30,000 a year do not have a highspeed Internet connection, compared with just $6 \%$ of such households earning $\$ 75,000$ or more a year. These broadband disparities are particularly pronounced for Black and Hispanic households with school-age children.

Several education systems, such as California's Lindsey Unified School District, support teachers in adapting to online education (Dede 2020). In Wuhan, China, the government "instructed a quarter of a billion full-time students to resume their studies through online platforms. This resulted in the largest online movement in the history of education, with approximately 730,000 , or $81 \%$ of K-12 students, attending classes via the Tencent K-12 Online School in Wuhan" (Li and Lalani 2020). Where families do not have access to the Internet, teachers can mail teaching materials and homework to their students. For example, school buses have delivered meals and classwork to some students in Manchester, UK, and in San Juan County, Utah, US (Phelps 2020; Tanner and Podmore 2020).

Second, teachers have a duty to support parents of children schooling at home by listening to their concerns and ensuring that they have the resources they need. Teachers must define their expectations, which must be reduced and adapted to the particular situation and set specific and realistic goals (Arvisais et al. 2020; Müller and Goldenberg 2020; UNICEF 2020), particularly in view of the difficulties that parents and students sometimes have in interpreting educational programs. Indeed, it is the responsibility of each teacher to provide a clear plan - which should be based on a formal education program, but whose organization is the teacher's responsibility-for his or her students to continue distance 
education until schools reopen (Arvisais et al. 2020). Rather than focus on new learning, distance education must work toward ensuring that learning achievements are maintained and consolidated.

Finally, teachers must identify and address the specific needs of their students, whether they are substantial basic needs or educational needs (Arvisais et al. 2020). To do this, the teacher should establish communication with the family as soon as schools are closed (EdTech Hub 2020) and maintain regular communication throughout the closure. It is widely recognized in education science that the teacher-student bond influences success (Valiente et al. 2019), and this bond is necessarily weakened in distance education; of its six characteristics - or six distances (Jacquinot 1993) — pedagogical distance is the most difficult to regulate, and technology can not eliminate it (Jacquinot-Delaunay 2010). This issue should be addressed as part of the development phase, especially if school is to continue on a distance or hybrid model, to ensure that the teacher-student bond does not suffer as much from crisis situations in the future.

\section{Effects of the crisis on students}

Educational science widely acknowledges that prolonged school absence can have significant effects on students (Balfanz and Byrnes 2012; Sims 2020). Studies on learning loss during summer break suggest that this period of interruption particularly affects young children at the pivotal time when they are learning to read and count; similarly, the rapid and important learning that takes place during the regular school year can turn into significant losses during an unplanned school closure (Müller and Goldenberg 2020).

An American study found that students who have just completed grade 4 lose an average of $27 \%$ of their math skills and $20 \%$ of their reading skills over the summer holidays, the latter being less affected because students read on their own during the summer months (Kuhfeld 2019). Moreover, Müller and Goldenberg (2020) have shown that along with summer learning loss, students also risk losing the learning they could have gained by the end of the school year. To estimate the loss of learning during the extended outage related to the current pandemic, Kuhfeld and Tawasara (2020) cross-tabulated the results on summer learning loss and student learning gains during a normal school year. Their projections suggest that with a reopening in September, students in grades 3-8 could return to school having lost about $50 \%$ of their math and $30 \%$ of their reading achievement or even be a full year behind the progress normally expected.

The effects of prolonged school closures are particularly significant for students with special needs and from disadvantaged backgrounds (Berkman 2008). Students with special needs, including those with adjustment or learning difficulties, cannot always study independently or autonomously (Müller and Goldenberg, 2020). Moreover, pupils from disadvantaged backgrounds do not necessarily have the resources to attend school at a distance. For example, in Switzerland, Norway, and Austria, 95\% of students have access to a computer at home, but this proportion is $50 \%$ or less in Turkey, Colombia, Brazil, Mexico, Thailand, and Peru (Reimers and Schleicher 2020). In several emerging countries, Internet access is also very limited or nonexistent for many families (Hares and Mundy 2020).

The Covid-19 pandemic highlights the digital divide (UN 2020a). For example, in subSaharan Africa, three-quarters of the population have cell phones, but only one-third have smartphones that can be used for learning (EdTech Hub 2020). Even in the United States, $25 \%$ of students from disadvantaged backgrounds do not have access to a computer for 
schoolwork (Li and Lalani 2020). Finally, prolonged and unexpected school closure may also contribute to students' dropping out, particularly those from disadvantaged backgrounds (Iqbal et al. 2020).

School closures have major effects on the physical and psychological health of many young people, particularly the most vulnerable (Charland et al. 2020; WHO 2020a). Exposure to stressful or traumatic circumstances can affect learning, cognition, and behavior, in addition to fostering emotional and social isolation (Müller and Goldenberg 2020). These effects are magnified by the lack of structure, routine, and stimulation normally provided by the school environment (WHO 2020a). These factors have an even greater impact on young people with mental health problems (Müller and Goldenberg 2020).

Students' physical health may be compromised when the school can no longer substantially meet their food and safety needs. This is particularly important for students from disadvantaged backgrounds, many of whom rely on free or low-cost school food services (Forsey 2017; Stewart et al. 2018). School closures also remove the safety net for students who experience family violence, which may result in fewer reports to child protection services, as has been the case in Quebec (Nadeau and Pineda 2020). "Being at home can place some children at increased risk of, or increased exposure to, child protection incidents or make them witness to interpersonal violence if their home is not a safe place" (WHO 2020a). UNICEF (2020) recommends that even during school closures, schools continue to provide basic services to vulnerable students, including protection and sufficient and healthy food.

\section{Effects of the crisis on subject matter}

Regarding the content of educational programs, UNICEF (2020) recommends reducing expectations and eliminating formal evaluations where possible. For example, consideration could be given to retaining only those examinations that promote students to a higher level. If most exams are canceled or suspended, programs in which students prepare for them are no longer needed (Loescher 2020). Since distance education does not offer the same opportunities as face-to-face instruction, it becomes necessary to prioritize curricular content and identify specific elements that students can work on, ideally at their own pace and according to their own interests and abilities (Arvisais et al. 2020; Reimers and Schleicher 2020).

Reimers and Schleicher (2020) conducted a survey in March 2020 on the educational issues raised by the pandemic, the responses to these issues, and the means put in place to provide education during confinement. The survey included respondents across 98 countries from the OECD and the Global Education Innovation Initiative of the Harvard Graduate School of Education networks. Of the 330 respondents, 277 believe that it is somewhat or very important to "ensure the continuity of academic learning for students", and 212 find it somewhat or very important to "define new curricular priorities during the crisis".

UNESCO International Institute for Educational Programming (IIEP) (2020) proposes to plan, for example, "an accelerated syllabus that focuses on core subjects". Government educational authorities should decide on these core subjects (Arvisais et al. 2020) during the reconstruction phase-meaning there should be more institutionalized measures - and should target "areas where learning loss will be most consequential for learning progression in the coming school year" (Hares and Mundy 2020)—namely, language and mathematics (Kuhfeld 2019). Moreover, priorities must necessarily be differentiated according to the age and level of pupils. For primary school students, especially younger students, it 
is critical to ensure strategies for pedagogical continuity of essential literacy and numeracy learning (Hares and Mundy 2020). It is also important to respect children's cognitive abilities so as not to overload them.

The UCCD (2020b) brought together several of its researchers and other curriculum developers to establish a list of curricular priorities to promote the maintenance and consolidation of primary and secondary school children's learning. They recommend that primary school children practice reading using short texts to work on language fluency and comprehension. For writing, the UCCD emphasizes handwriting, using short dictations and creative writing. For example, encouraging students to write about what they experienced during confinement can help them vent and communicate their feelings. In mathematics, activities should be meaningful, authentic, and concrete to the extent possible. For example, it is possible to work on arithmetic skills with household objects or everyday situations and to work on geometry and measurement skills by mixing exercises with artistic or technical activities. Older students can also work with statistics by investigating their environment, for example in problem-solving activities. Another UCCD priority, problem-solving, is a core competency in several curricula, including science and mathematics (Rajotte 2017), and can be experienced in several investigative activities. Some educational video games or "serious" games with a pedagogical intent also allow for problem-solving (Roberge 2017). However, this last option raises the issue of screen-time management, part of the last UCCD curricular priority - health and physical education. In this regard, WHO (2010) recommends that children get at least 60 minutes of physical activity - sports or active gamesevery day and emphasizes that the activities be varied and regular. As for screen time, WHO (2019) recommends that children get no screen-time before 2 years old, less than an hour between 2 and 5 years old, and less than two hours daily after five years old. In addition, other priorities related to diet and sleep should be added (Gadais and Deschênes 2020).

For high school students, it is imperative to support motivation and engagement, particularly among students at risk of dropping out or with learning difficulties (Hares and Mundy 2020). The UCCD (2020c) has established a list of curricular priorities to promote the maintenance and consolidation of learning in secondary school, including at least 30-60 min of reading time each day-depending on the age and level of the student-from varying genres (fiction and non-fiction) while respecting students' interests. For writing, it is also important to respect student's interests and creativity and to have them write regularly in a variety of genres at a level appropriate to their grade. Teachers can work with language and the capacity for synthesis through several authentic situations-for example, by asking the student to describe, relate, summarize, or explain an event or phenomenon. In mathematics, high school students learn to interpret and communicate reality mathematically; it is therefore important that they remain active in their learning - appropriate to their grade and skill level-by regularly practicing arithmetic, algebra, probability, statistics, geometry, and analytical geometry (Kuhfeld and Tarawasa 2020). In social and human sciences, the UCCD recommends focusing on, among other things, the understanding of timelines and maps, the ability to ask questions about the world, and the capacity to judge the relevance of information sources, skills that are particularly useful in the current era of unreliable information (Boberg et al. 2020; Laato et al. 2020). In science, scientific or technological investigation activities can be carried out using household objects and everyday situations, and the focus should be on the steps of a scientific or technological design process. Finally, in health and physical education, the UCCD recommends 
that students continue to develop their physical, cognitive, psychological, and social health, particularly during confinement, when their lifestyles are disrupted (Gadais and Deschênes 2020).

\section{Effects of the crisis on milieu}

When schools reopen, the modalities of physical distancing imply important changes in practices and, more broadly, educational settings. The first crucial issue is the appropriate timing for reopening. "Too early and the public health is in danger, longer than necessary and the learning loss will continue to aggravate, especially for the most vulnerable" (UNESCO 2020c). Reopening generates anxiety for many teachers and parents, even where it has been declared safe provided strict measures of hygiene and physical distancing are respected (Adams and Sample 2020; Arvisais et al. 2020; Coughlan and Richardson 2020). Such measures are mainly based on past responses to epidemics and are part of temporary activities put in place to get educators back into action, as is the case in the recovery phase.

No consensus yet exists on the extent to which children are vectors of Covid-19 transmission. Although there is evidence that they may be infected (Liu et al. 2020), it appears that their symptoms are milder than those of adults and that they recover more quickly (Castagnoli et al. 2020; Gudbjartsson et al. 2020). Tracking studies conducted in several countries also suggest that children play a lesser role in transmission (RIVM 2020) and that transmission in schools, compared to that in families, is limited (Cauchemez et al. 2009; National Centre for Immunisation Research and Surveillance 2020; Viner et al. 2020). However, because adults in schools are more important vectors of contagion, they must observe strict physical distancing measures (RIVM 2020). With all the considerations teachers must assess during a pandemic, one may wonder how much opportunity remains for teaching itself. Indeed, whereas most studies on the reopening of schools during Covid19 focus mainly on health measures, few offer recommendations on pedagogical content.

Hygiene and physical distancing measures required for school reopening may depend on the age and grade level of the students (Kingsley 2020). For example, since transmission of the virus is related to the dynamics of group members (Barratt et al. 2018), there is no ideal class size, which may vary according to the characteristics of the students (age, maturity, cognitive abilities, disability, etc.), while measures may include limits on the number of students per group or per room. Indeed, the organization of the premises must allow sufficient distance between all persons (WHO 2020b).

A partial reopening or hybrid model of education may be viable options-for example, reopening primary but not secondary schools or rotating groups of students on-site on a part-time basis (WHO 2020b). Primary schools should be reopened before secondary schools since, in the younger age group, the risks are lower compared to the benefits of face-to-face education (UNICEF 2020; Vanhems 2020).

For school reopening, hygiene remains the most important element and involves frequent handwashing, as much as possible with soap and water; waste management; and refraining from sharing objects (UNICEF 2020). In addition, students and teachers should check for symptoms of Covid-19 and avoid coming to school if they are infected (Evershed and Ball 2020; Tan 2006). It is absolutely essential that mechanisms for tracking school contacts and school travel be put in place to monitor the dynamics of virus transmission (Viner et al. 2020) as part of the fourth phase of the continuum, development, to prepare, the school system's response to future epidemic crises. 
At the time of this writing, many countries have partially or fully reopened their schools. There is no clear picture of the measures taken in these various institutions internationally, but it is possible to observe some trends. For example, in Spring 2020 in Quebec and New Zealand, parents were free to decide whether their children will return to school or complete the school year from home (Government of Quebec 2020; Ward 2020). Several countries have preferred partial or gradual reopening plans. In Denmark, Israel, and Norway, younger students returned to school first; in some parts of China, high school students were first to return (Cavanagh 2020). In Quebec, primary students returned first except in the regions most affected by Covid-19, where schools remained closed until September (Government of Quebec 2020), as in some of the most affected countries in Europe, including Italy and Spain (Müller and Goldenberg 2020). Most countries have adopted physical distancing measures, with six feet required between students when they are in line or sitting at their desks. This is the case in Denmark, Israel, Norway, Germany, Vietnam, and China; in China, some students even wear hats that extend six feet in diameter around them (Cavanagh 2020; Ward 2020).

Class sizes have also been drastically reduced in some schools in Denmark and Norway, and students have designated classroom or cafeteria seats in South Korea, Germany, and Japan (Cavanagh 2020; Strauss 2020; Ward 2020). Of course, handwashing is mandatory - and its frequency is regulated - in almost all countries; premises, furniture, and toys are disinfected once or several times a day in most schools (Cavanagh 2020; Strauss 2020). Wearing masks in schools is mandatory, particularly in Taiwan, Israel, Germany, and South Korea (Cavanagh 2020; Strauss 2020; Ward 2020; Javid et al. 2020; Leung et al. 2020) and some countries have adopted other health measures, such as mandatory temperature testing before entering a school or partition walls on all desks (Cavanagh 2020; Strauss 2020). In Germany, where classroom windows are kept open to promote air circulation, schools ask students to make sure they have adequate clothing (Ward 2020).

\section{Effects on parents and their place in the curriculum}

Connelly and Xu's (2008) model, though it allows for a multidimensional view of the curriculum, has an important limitation, in that it does not specifically include parents. As Schubert (2008) points out, the enacted curriculum is complex and influenced by many contributors, including parents. Although the impact of parental involvement is widely acknowledged in education science (Đurišić and Bunijevac 2017), parents and families are too often invalidated or rendered invisible in curricula and are a milieu that deserves equal rank with the school and classroom (Pushor 2009). The Covid-19 crisis might thus be an opportunity to reappraise the role of parents, who have been neglected in the conceptualization of the curriculum.

Parents have been asked to assume a coeducational role during the pandemic for which they are not necessarily prepared or equipped and are subject to significant pressures and tensions (Cipriano and Brackett 2020). They have a critical role to play with respect to illness, hygiene, physical distancing measures, and managing the emotions associated with a crisis (Murray 2010). Parents may find it difficult to support their children's learning, especially if their resources and educational level are limited or if they have no alternative but to continue working (Arvisais et al. 2020; UNESCO 2020b). Conversely, they can suffer significant economic losses if they must take regular time off work to care for their children (UNESCO 2020b). To support parents in these new and challenging roles, teachers must use their professional judgment and consider every family's particular situation. For 
example, schools can support learning at home by providing parents with "information for families on skills required for students in all subjects at each grade, information on homework policies and how to monitor and discuss schoolwork at home" (Đurišić and Bunijevac 2017), with the aim of strengthening the partnership between these two milieus-school/ classroom and family/parents.

\section{Conclusions}

Education systems are often said to be commensurate with a nation's level of development, whether they are in an emerging or institutionalized country. However, the SARS-CoV-2 pandemic has brutally highlighted the fragility of all education systems worldwide. During and after the crisis, education systems must address the questions emerging from this exceptional situation: Is distance or hybrid education possible in our model? Are our students sufficiently equipped and autonomous to continue their learning despite the pedagogical distance? Are they dependent on teachers for access to quality educational resources? When a crisis occurs, how can our system make a rapid transition from face-to-face to distance education?

As noted earlier, crises imply danger but also opportunity (Darling 1994); the term crisis in itself suggests that there is time to prevent disaster (Boin and T' Hart 2007). Crises are associated with openness toward the future and the need for radical decision-making (Kornberger et al. 2019). Following the continuum of education crises (UCCD 2020a), education systems tend to return to the development phase, where they are forced to question their stability and flexibility, the level of training of education actors, the capacity of the system to cope with an emergency situation, and the need to put in place action plans to return or move to a stable and institutionalized system able to cope with future crises. To become more resilient, education systems must learn from this crisis by monitoring its effects on all dimensions of the curriculum: teachers, students, subject matter, and milieu (including in the latter schools and family in a place of equal rank).

\section{References}

Adams, R., \& Sample, I. (2020, May 22). Ministers rejected school reopening plan recommended by Sage experts. The Guardian. https:/www.theguardian.com/education/2020/may/22/ministers-rejectedschool-reopening-plan-recommended-by-sage-experts.

Active Learning Network for Accountability and Performance (2010). Disaster risk management cycle (DRMC) and effective disaster risk reduction (DRR) diagrams. https://www.alnap.org/help-library/ disaster-risk-management-cycle-drmc-and-effective-disaster-risk-reduction-drr-diagrams.

Anderson, R. M., Heesterbeek, H., Klinkenberg, D., \& Hollingsworth, T. D. (2020). How will countrybased mitigation measures influence the course of the Covid-19 epidemic? The Lancet, 395(10228), 931-934. https://doi.org/10.1016/S0140-6736(20)30567-5.

Arvisais, O., Deslandes Martineau, M., \& Charland, P. (2020, May 27). A shout-out to teachers: Why their expertise matters in the coronavirus pandemic, and always. The Conversation. https://theconversation .com/a-shout-out-to-teachers-why-their-expertise-matters-in-the-coronavirus-pandemic-and-alway s-136575.

Arvisais, O., Merckx, J.-T., Turgeon, N., \& Charland, P. (2020, May 4). Réouverture des écoles primaires: Mode d'emploi [How to re-open primary schools]. The Conversation. https://theconversation.com/ reouverture-des-ecoles-primaires-mode-demploi-137477.

Azzi-Huck, K., \& Tigran, S. (2020, March 18). Managing the impact of Covid-19 on education systems around the world: How countries are preparing, coping, and planning for recovery. Washington, DC: 
World Bank. https://blogs.worldbank.org/education/managing-impact-covid-19-education-systemsaround-world-how-countries-are-preparing.

Balfanz, R., \& Byrnes, V. (2012). The importance of being in school: A report on absenteeism in the nation's public schools. The Education Digest, 78(2), 4-9.

Barratt, H., Kirwan, M., \& Shantikumar, S. (2018). Epidemic theory (effective \& basic reproduction numbers, epidemic thresholds) \& techniques for analysis of infectious disease data (construction \& use of epidemic curves, generation numbers, exceptional reporting \& identification of significant clusters). Health Knowledge. https://www.healthknowledge.org.uk/public-health-textbook/research-metho ds/1a-epidemiology/epidemic-theory.

BBC News (2020, April 1). Coronavirus: Greatest test since World War Two, says UN chief. BBC News. https://www.bbc.com/news/world-52114829.

Berkman, B. E. (2008). Mitigating pandemic influenza: The ethics of implementing a school closure policy. Journal of Public Health Management and Practice, 14(4), 372-378. https://doi.org/10.1097/01. PHH.0000324566.72533.0b.

Boberg, S., Quandt, T., Schatto-Eckrodt, T., \& Frischlich, L. (2020). Pandemic populism: Facebook pages of alternative news media and the corona crisis-A computational content analysis. ArXiv:2004.02566 [Cs]. http://arxiv.org/abs/2004.02566.

Boin, A., \& T' Hart, P. (2007). The crisis approach. In H. Rodríguez, E. L. Quarantelli, \& R. R. Dynes (Eds.), Handbook of disaster research (pp. 42-54). New York, NY: Springer. https://doi. org/10.1007/978-0-387-32353-4_3.

Breault, D. A., \& Marshall, J. D. (2010). Definitions of curriculum. In C. Kridel (Ed.), Encyclopedia of curriculum studies (pp. 179-182). Beverly Hills, CA: SAGE.

Brinks, V., \& Ibert, O. (2020). From corona virus to corona crisis: The value of an analytical and geographical understanding of crisis. Tijdschrift Voor Economische En Sociale Geografie, 111(3), 275-287. https://doi.org/10.1111/tesg.12428.

Burde, D., Guven, O., Kelcey, J., Lahmann, H., \& Al-Abbadi, K. (2015). What works to promote children's educational access, quality of learning, and wellbeing in crisis-affected contexts. London: UK. Department for International Development (DFID). http://s3.amazonaws.com/inee-assets/resources/ Education-emergencies-rigorous-review-2015-10.pdf.

Burns, M. (2020, April 1). School, interrupted: 4 options for distance education to continue teaching during Covid-19. Global Partnership for Education. https://www.globalpartnership.org/blog/school-inter rupted-4-options-distance-education-continue-teaching-during-covid-19.

Castagnoli, R., Votto, M., Licari, A., Brambilla, I., Bruno, R., Perlini, S., et al. (2020). Severe acute respiratory syndrome coronavirus 2 (SARS-CoV-2) infection in children and adolescents: A systematic review. JAMA Pediatrics. https://doi.org/10.1001/jamapediatrics.2020.1467.

Cauchemez, S., Ferguson, N. M., Wachtel, C., Tegnell, A., Saour, G., Duncan, B., et al. (2009). Closure of schools during an influenza pandemic. The Lancet Infectious Diseases, 9(8), 473-481. https://doi. org/10.1016/S1473-3099(09)70176-8.

Cavanagh, E. (2020). How 6 countries are opening up schools again, with temperature checks, outdoor classes, and spaced out desks. Insider. https://www.insider.com/how-china-denmark-japan-reopeningschools-2020-4.

Charland, P., Coulombe, C., Bluteau, J., Turgeon, N., \& Arvisais, O. (2020, April 28). Covid-19: Pourquoi il faut rouvrir les écoles maintenant [Why we should reopen schools now]. The Conversation. https:// theconversation.com/covid-19-pourquoi-il-faut-rouvrir-les-ecoles-maintenant-137051.

Cipriano, C., \& Brackett, M. (2020). Teacher, interrupted: Leaning into social-emotional learning amid the Covid-19 crisis. EdSurge. https:/www.edsurge.com/news/2020-03-18-teacher-interrupted-leani ng-into-social-emotional-learning-amid-the-covid-19-crisis.

Connelly, F. M., \& Xu, S. (2008). The landscape of curriculum and instruction: Diversity and continuity. In F. M. Connelly, M. F. He, \& J. Phillion (Eds.), The SAGE handbook of curriculum and instruction (pp. 514-533). Beverly Hills, CA: SAGE.

Coughlan, S., \& Richardson, H. (2020, May 22). Teachers' unions 'unconvinced' safe to open schools. $B B C$ News. https://www.bbc.com/news/education-52771515.

Darling, J. R. (1994). Crisis management in international business: Keys to effective decision making. Leadership \& Organization Development Journal, 15(8), 3-8. https://doi.org/10.1108/014377394100730 47.

Dede, C. (2020). Remote learning and stone soup. Washington, DC: Learning Policy Institute. https://learn ingpolicyinstitute.org/blog/remote-learning-and-stone-soup.

Durand, M.-J. (1996). État de la question du curriculum conduisant à la conception d'un réseau notionnel $d u$ domaine [State of the question of curriculum, towards building a conceptual map of the field]. $\mathrm{PhD}$ thesis. Université du Québec à Montréal. 
Đurišić, M., \& Bunijevac, M. (2017). Parental involvement as an important factor for successful education. Center for Educational Policy Studies Journal, 7(3), 137-153.

EdTech Hub (2020). Five things to think about for out-of-school learning during the coronavirus (Covid19) outbreak. EdTech Hub. https://edtechhub.org/2020/03/24/five-things-out-of-school-learningduring-the-coronavirus-outbreak/.

EduScol (2015). Qu'est-ce que l'état d'urgence? [What is the state of emergency?]. Paris: EduScolMinistère de l'Éducation Nationale. https://eduscol.education.fr/cid95473/qu-est-ce-que-1-etat-durgence.html.

Evershed, N., \& Ball, A. (2020, April 22). How coronavirus spreads through a population and how we can beat it. The Guardian. https://www.theguardian.com/world/datablog/ng-interactive/2020/ apr/22/see-how-coronavirus-can-spread-through-a-population-and-how-countries-flatten-thecurve.

Figley, C. R. (Ed.) (1995). Compassion fatigue: Coping with secondary traumatic stress disorder in those who treat the traumatized. New York, NY: Brunner/Mazel.

Forsey, A. (2017). Hungry holidays: A report on hunger amongst children during school holidays. http:// www.frankfield.co.uk/upload/docs/Hungry\%20Holidays.pdf.

Gadais, T., \& Deschênes, M. (2020, April 8). How to keep your children active and healthy while in coronavirus isolation. The Conversation. https://theconversation.com/how-to-keep-your-childrenactive-and-healthy-while-in-coronavirus-isolation-134973.

Gérard, E. (2001). La demande d'éducation en Afrique: Approches sociologiques [Education demand in Africa: Sociological approaches]. In M. Pilon \& Y. Yaro (Eds.), La demande d'éducation en Afrique: État des connaissances et perspectives de recherche (pp. 63-79). Dakar: Réseaux Thématiques de Recherche de l'UEPA. https://horizon.documentation.ird.fr/exl-doc/pleins_textes/plein s_textes_7/divers2/010029632.pdf.

Gouvernement du Québec (2020). Questions and answers on education and families during the Covid19 pandemic. Québec: Gouvernement du Québec. https://www.quebec.ca/en/health/health-issue s/a-z/2019-coronavirus/answers-questions-coronavirus-covid19/questions-answers-educationfamilies-covid-19/.

Gudbjartsson, D. F., Helgason, A., Jonsson, H., Magnusson, O. T., Melsted, P., Norddahl, G. L., et al. (2020). Spread of SARS-CoV-2 in the Icelandic population. New England Journal of Medicine. https://doi.org/10.1056/NEJMoa2006100.

Guterres, A. (2020). We are all in this together: Human rights and Covid-19 response and recovery. New York, NY: UN. https://www.un.org/fr/un-coronavirus-communications-team/we-are-all-toget her-human-rights-and-covid-19-response-and.

Hares, S., \& Mundy, K. (2020). Equity-focused approaches to learning loss during Covid-19. UKFIETThe Education and Development Forum. https://www.ukfiet.org/2020/equity-focused-approaches -to-learning-loss-during-covid-19/.

Iqbal, S. A., Azevedo, J. P., Geven, K., Hasan, A., \& Patrinos, H. A. (2020). We should avoid flattening the curve in education-Possible scenarios for learning loss during the school lockdowns. Washington, DC: World Bank. https://blogs.worldbank.org/education/we-should-avoid-flattening-curve -education-possible-scenarios-learning-loss-during-school.

Jacquinot, G. (1993). Apprivoiser la distance et supprimer l'absence ? Ou les défis de la formation à distance [Managing distance and suppressing absence? Challenges of remote learning]. Revue française de pédagogie, 102(1), 55-67. https://doi.org/10.3406/rfp.1993.1305.

Jacquinot-Delaunay, G. (2010). Entre présence et absence: La FAD comme principe de provocation [Presence and absence: Remote learning as a provocation principle]. Distances et Savoirs, 8(2), $153-165$.

Javid, B., Weekes, M. P., \& Matheson, N. J. (2020). Covid-19: Should the public wear face masks? BMJ. https://doi.org/10.1136/bmj.m1442.

Jonnaert, P. (2015). Indicateurs pour une évaluation globale d'un curriculum [Indicators for a global evaluation of a curriculum]. Geneva: UNESCO IBE.

Joseph, P. B. (2011). Cultures of curriculum. London: Routledge.

Kingsley, P. (2020). In Denmark, the rarest of sights: Classrooms full of students. The New York Times. https://www.nytimes.com/2020/04/17/world/europe/denmark-schools-coronavirus.html.

Kornberger, M., Leixnering, S., \& Meyer, R. E. (2019). The logic of tact: How decisions happen in situations of crisis. Organization Studies, 40(2), 239-266. https://doi.org/10.1177/0170840618814573.

Kuhfeld, M. (2019). Surprising new evidence on summer learning loss. Phi Delta Kappan, 101(1), 25-29. https://doi.org/10.1177/0031721719871560.

Kuhfeld, M., \& Tarawasa, B. (2020). Technical appendix for the Covid-19 slide: What summer learning loss can tell us about the potential impact of school closures on student academic achievement. 
Portland, OR: NWEA. https://www.nwea.org/content/uploads/2020/04/COVID-technical-appen dix_2020.04.08.pdf.

Laato, S., Islam, A. K. M. N., Islam, M. N., \& Whelan, E. (2020). Why do people share misinformation during the Covid-19 pandemic? ArXiv:2004.09600 [Cs]. http://arxiv.org/abs/2004.09600.

Leung, N. H. L., Chu, D. K. W., Shiu, E. Y. C., Chan, K.-H., McDevitt, J. J., Hau, B. J. P., et al. (2020). Respiratory virus shedding in exhaled breath and efficacy of face masks. Nature Medicine, 26(5), 676-680. https://doi.org/10.1038/s41591-020-0843-2.

Li, C., \& Lalani, F. (2020). The Covid-19 pandemic has changed education forever. This is how. World Economic Forum. https://www.weforum.org/agenda/2020/04/coronavirus-education-global-covid 19-online-digital-learning/?fbclid=IwAR1YJ7v0sQsWtelQ4dcT_vnqEkM_bZjr36rAisbZ1b-eY3fq awHZx0GHuT4.

Liu, W., Zhang, Q., Chen, J., Xiang, R., Song, H., Shu, S., et al. (2020). Detection of Covid-19 in children in early January 2020 in Wuhan, China. New England Journal of Medicine, 382(14), 1370-1371. https:// doi.org/10.1056/NEJMc2003717.

Loescher, S. (2020). From risk averse to risk immersed: Leading schools through a paradigm-shattering event. Silver Lining for Learning-Conversations about the Future of Education. https://silverlini ngforlearning.org/from-risk-averse-to-risk-immersed-leading-schools-through-a-paradigm-shattering -event-part-1-of-3/.

Lollia, M., \& Issaieva, E. (2020). Comment les enseignants assurent la continuité pédagogique et évaluent en contexte de pandémie ? Une étude en Guadeloupe. Évaluer. Journal International de Recherche En Éducation et Formation, (1), 181-192.

Müller, L.-M., \& Goldenberg, G. (2020). Education in times of crisis: The potential implications of school closures for teachers and students. London: Chartered College of Teaching. https://my.chartered.colle ge/wp-content/uploads/2020/05/CCTReport150520_FINAL.pdf.

Murray, C. J. S. (2010). A collaborative approach to meeting the psychosocial needs of children during an influenza pandemic. Journal for Specialists in Pediatric Nursing, 15(2), 135-143. https://doi.org/10.1 111/j.1744-6155.2009.00229.x.

Nadeau, J.-F., \& Pineda, A. (2020). Baisse des signalements à la DPJ: Une illusion? Le Devoir. https://www. ledevoir.com/societe/575689/maltraitance-baisse-des-signalements-a-la-dpj.

NCIRS [National Centre for Immunisation Research and Surveillance] (2020). Report: Covid-19 in schools-The experience in NSW. Sydney: NCIRS. http://ncirs.org.au/covid-19-in-schools.

Peterson, J., Pearce, P. F., Ferguson, L. A., \& Langford, C. A. (2017). Understanding scoping reviews: Definition, purpose, and process. Journal of the American Association of Nurse Practitioners, 29(1), 12-16. https://doi.org/10.1002/2327-6924.12380.

Pfefferbaum, B., Gurwitch, R. H., Doughty, D. E., Foy, D. W., Pfefferbaum, R. L., Pynoos, R. S., et al. (2004a). Teachers' psychological reactions 7 weeks after the 1995 Oklahoma City bombing. American Journal of Orthopsychiatry, 74(3), 263-271.

Pfefferbaum, R. L., Fairbrother, G., Brandt, E. N., Robertson, M. J., Gurwitch, R. H., Stuber, J., et al. (2004b). Teachers in the aftermath of terrorism: A case study of one New York City school. Family \& Community Health, 27(3), 250-259.

Phelps, J. (2020, March 16). School districts use buses to deliver meals, homework. New Hampshire Union Leader. https:/www.unionleader.com/news/health/coronavirus/school-districts-use-buses-to-delivermeals-homework/article_899147e4-c19e-5f15-a39b-942afd88e7b3.html.

Pushor, D. (2009). The situation of parents in the curricular commonplaces: A place of equal rank? Learning Landscapes, 2(2), 139-154. https://doi.org/10.36510/learnland.v2i2.300.

Rajotte, T. (2017). L'enseignement et l'apprentissage par la résolution de problèmes mathématiques: Quelles stratégies privilégier? [What strategies to choose when teaching and learning with mathematical problem solving?]. Vivre Le Primaire, Été, 2017, 22-25.

Reimers, F. M., \& Schleicher, A. (2020). A framework to guide an education response to the Covid-19 pandemic of 2020. Paris: OECD. https://globaled.gse.harvard.edu/files/geii/files/framework_guide _v2.pdf.

RIVM [National Institute for Public Health and the Environment/Rijksinstituut voor Volksgezondheid en Milieu] (2020). Children and Covid-19. Dutch National Institute for Public Health and the Environment - Ministry of Health, Welfare and Sport. https:/www.rivm.nl/en/novel-coronavirus-covid-19/ children-and-covid-19?fbclid=IwAR2cYbDKtyFnD3pHCJ9_NrUoEJrb37u6eoPz8FXNkGiOP7Jh8V _pUBSE0sI.

Reuter, Y., Cohen-Azria, C., Daunay, B., Delcambre, I., \& Lahanier-Reuter, D. (2007). Dictionnary of the fundamentals of didactics. Bruxelles: De Boeck. 
Roberge, M. (2017). Exploiter les jeux numériques pour favoriser l'apprentissage: Mission possible! [Using digital games for learning: Mission possible!]. École Branchée. https://ecolebranchee.com/exploiterles-jeux-numeriques-pour-favoriser-lapprentissage-mission-possible/.

Schiro, M. (2012). Curriculum theory: Conflicting visions and enduring concerns. Beverly Hills, CA: SAGE.

Schubert, W. H. (2008). Curriculum inquiry. In The SAGE handbook of curriculum and instruction (pp. 399-419). https://doi.org/10.4135/9781412976572.n19.

Schwab, J. J. (1973). The practical 3: Translation into curriculum. The School Review, 81(4), 501-522.

Shaluf, I. M., Ahmadun, F., \& Mat Said, A. (2003). A review of disaster and crisis. Disaster Prevention and Management: An International Journal, 12(1), 24-32. https://doi.org/10.1108/0965356031 0463829.

Sims, S. (2020). School absences and pupil achievement. London: Centre for Education Policy and Equalising Opportunities, UCL Institute of Education. https://ideas.repec.org/p/ucl/cepeob/1.html.

Sucharew, H., \& Macaluso, M. (2019). Methods for research evidence synthesis: The scoping review approach. Journal of Hospital Medicine. . https://doi.org/10.12788/jhm.3248.

Stewart, H., Watson, N., \& Campbell, M. (2018). The cost of school holidays for children from low income families. Childhood, 25(4), 516-529. https://doi.org/10.1177/0907568218779130.

Strauss, V. (2020). The pictures say it all: How South Korean schools are reopening. The Washington Post. https://www.washingtonpost.com/education/2020/05/26/pictures-say-it-all-how-south-korea n-schools-are-reopening/.

Tan, C.-C. (2006). SARS in Singapore-Key lessons from an epidemic. Annals of the Academy of Medicine, Singapore, 35(5), 345-349.

Tanner, C. \& Podmore, Z. (2020). During coronavirus outbreak, school buses are delivering food and homework to Utah students in rural communities. The Salt Lake Tribune. https:/www.sltrib.com/ news/2020/03/31/during-coronavirus/.

UN [United Nations] (1992). Internationally agreed glossary of basic terms related to disaster management. New York, NY: UN. https://reliefweb.int/sites/reliefweb.int/files/resources/004DFD3E15 B69A67C1256C4C006225C2-dha-glossary-1992.pdf.

UN (2020a). Coronavirus reveals need to bridge the digital divide. United Nations Conference on Trade and Development. https://unctad.org/en/pages/newsdetails.aspx? OriginalVersionID=2322.

UN (2020b). The impact of Covid-19 on children. Policy brief. New York, NY: UN. https://unsdg.un.org/ sites/default/files/2020-04/160420_Covid_Children_Policy_Brief.pdf.

UNDP [UN Development Programme] (2020). Disaster recovery. New York, NY: UNDP. https://www. undp.org/content/undp/en/home/2030-agenda-for-sustainable-development/planet/disaster-riskreduction-and-recovery/disaster-recovery.html.

UNHCR [UN High Commissioner for Refugees] (2006). UNHCR master glossary of terms (Rev.1). Geneva: UNHCR. https://www.refworld.org/docid/42ce7d444.html.

UNESCO (2015). Rethinking education: Towards a global common good? Paris: UNESCO. https:// unesdoc.unesco.org/ark:/48223/pf0000232555_eng

UNESCO (2020a). Distance learning solutions. Paris: UNESCO. https://en.unesco.org/covid19/educa tionresponse/solutions.

UNESCO (2020b). 1.37 billion students now home as COVID-19 school closures expand, ministers scale up multimedia approaches to ensure learning continuity. Paris: UNESCO. https://en.unesco.org/ news/137-billion-students-now-home-covid-19-school-closures-expand-ministers-scale-multimedia.

UNESCO (2020c). Back to school: Preparing and managing the reopening of schools. Paris: UNESCO. https://fr.unesco.org/covid19/educationresponse.

UNESCO IIEP [ International Institute for Educational Planning] (2020). Plan for school reopening. Paris: UNESCO IIEP. http://www.iiep.unesco.org/en/plan-school-reopening.

UCCD [UNESCO Chair in Curriculum Development] (2020a). UNESCO Chair in Curriculum Development-Context. Montreal: Université du Québec à Montréal. https://cudc.uqam.ca/en/the-chair/.

UCCD (2020b). Covid-19-Conseils pour les parents afin de favoriser le maintien des apprentissages de leur enfant au primaire [Advice for parents to maintain their child's learning in primary school]. Montreal: Université du Québec à Montréal. https://cudc.uqam.ca/primaire/.

UCCD (2020c). Covid-19-Conseils pour les parents afin de favoriser le maintien des apprentissages de leur enfant au secondaire [Advice for parents to maintain their child's learning in secondary school]. Montreal: Université du Québec à Montréal. https://cudc.uqam.ca/secondaire/.

UNICEF (2020). Framework for reopening schools. New York, NY: UNICEF. https://www.unicef.org/ media/68366/file/Framework-for-reopening-schools-2020.pdf. 
Valiente, C., Parker, J. H., Swanson, J., Bradley, R. H., \& Groh, B. M. (2019). Early elementary studentteacher relationship trajectories predict girls' math and boys' reading achievement. Early Childhood Research Quarterly, 49, 109-121. https://doi.org/10.1016/j.ecresq.2019.05.001.

Vanhems, P. (2020). SARS-CoV2 infection and primary school closure. Eurosurveillance. https://doi. org/10.2807/1560-7917.ES.2020.25.15.2000617.

Viner, R. M., Russell, S. J., Croker, H., Packer, J., Ward, J., Stansfield, C., et al. (2020). School closure and management practices during coronavirus outbreaks including Covid-19: A rapid systematic review. The Lancet Child \& Adolescent Health, 4(5), 397-404. https://doi.org/10.1016/S2352 $-4642(20) 30095-X$.

Ward, A. (2020). Germany, Vietnam, and New Zealand have reopened schools. Here's what the US can learn. Vox. https://www.vox.com/21270817/coronavirus-schools-reopen-germany-vietnam-new-zeala nd.

WHO [World Health Organization] (2010). Global recommendations on physical activity for health. Geneva: WHO. http://www.ncbi.nlm.nih.gov/books/NBK305057/.

WHO (2019). To grow up healthy, children need to sit less and play more. Geneva: WHO. https://www.who. $\mathrm{int} /$ news/item/24-04-2019-to-grow-up-healthy-children-need-to-sit-less-and-play-more.

WHO (2020a). Mental health and psychosocial considerations during the Covid-19 outbreak. Geneva: WHO. https://www.who.int/docs/default-source/coronaviruse/mental-health-considerations.pdf?sfvrs $\mathrm{n}=6 \mathrm{~d} 3578$ af_2.

WHO (2020b). Considerations for school-related public health measures in the context of Covid-19. Geneva: WHO. https://www.who.int/publications-detail/considerations-for-school-related-publi c-health-measures-in-the-context-of-covid-19.

Publisher's Note Springer Nature remains neutral with regard to jurisdictional claims in published maps and institutional affiliations.

Patrick Charland is a full professor in the Department of Teaching at Université du Québec à Montréal. As a co-chairholder of the UNESCO Chair on curriculum development, his research program is mainly focused on comparative education issues, such as competency-based programs implementations, teacher training, teaching practices, competency assessment, and pedagogical material. His projects have been carried out in Canada, France, Chile, Democratic Republic of Congo, Madagascar, Iraq, Niger, Côte d'Ivoire, Togo, and Benin.

Marion Deslandes Martineau is pursuing a Master in Didactics at UQAM. She is also a studentresearcher for the UNESCO Chair in Curriculum Development and a student member of the Réseau des chercheur.e.s, associated with RÉPAQ (Réseau des écoles publiques alternatives du Québec). Her research focuses on the socioeducational environment of the alternative public schools in Quebec.

Tegwen Gadais is a professor in the Department of Physical Activities Sciences in UQAM. He has taught physical education in several European and Quebec educational institutions. He also has an expertise in the field of international cooperation and development where I continue to work with various organizations in developing countries. His current research focuses on the physical education, health education, outdoor physical activity and outdoor education; sport, for development and peace, physical activity and international development. as well as the development of the human being in a holistic and complex approach.

Olivier Arvisais is a professor in the Department of Teaching of the Faculty of Education at UQAM and Scientific Director of the Canadian Observatory on Crises and Humanitarian Aid (OCCAH). His research focuses mainly on the didactics of human and social sciences at primary and post-secondary levels, with a strong interest in education in emergency. Professor Arvisais regularly works as a consultant-researcher for UNHCR and other international organizations.

Nadia Turgeon is currently working as a professional with the UNESCO Chair in Curriculum Development (UCCD) at the University of Quebec at Montreal, where she is also pursuing her MA in Education. Her research focuses on educational neuroscience and immersive learning. She has expertise in the management of higher education training programs, as well as in the analysis of training needs and impact assessment. 
Valérie Vinuesa holds a master's degree in economics from the University of Auvergne and an MBA in strategic and entrepreneurial management from the Institut Supérieur de Commerce de Paris. Her background illustrates her interest in getting involved with young people, women, and immigrants from an entrepreneurial and humanitarian perspective. She participated in several missions in Niger related to LMD migration in West Africa, founded the International Summer School for Young Francophone Entrepreneurs at the Université de Sherbrooke and directed the one in Sousse, Tunisia, and participated in the development of female and agricultural entrepreneurship in Mali, before becoming pedagogical advisor in internationalization of education at the Marguerite Bourgeoys school board. Her doctoral project focuses on the integration of practical internships abroad for future teachers through a multicase study in Canada, France, and Brazil.

Stéphane Cyr is an associate professor in the mathematics department and co-chairholder of the UNESCO Chair in Curriculum Development at UQAM. He has been working for 20 years in the training of primary and secondary school teachers. He has done extensive work on curriculum reform at primary, secondary, and university level in several African countries. He helped support the education systems of these countries to improve the quality of teacher training in primary and secondary and has also developed several teaching materials adapted to these contexts. 